of the effect. Further, the spectra of compounds, if the atoms were not charged, should be simply related found to spectra of their constituents. This was not in question case. In short, two kinds of force were other on the structure of the atoms; the former bein generally the more important. From a chemical poin of view, in those combinations in which the force acting depended on the charges, it should be possible to substitute a similarly charged atom of another element without much disturbing the architecture of the compound as a whole. If, on the other hand, the hy drogen atoms in marsh gas were held by structura forces, the substitution of one by another element would alter the whol

With atoms built up as suggested in Fig. 2, the forces capable of holding another atom in stable equilibrium would be developed in certain directions only. These directions might be named "valency regions," and the general result would agree well with the hypothesis of Van t'Hoff and Le Bel as to the asymmetrical carbon atom, which they supposed to exert attraction in four definite directions. In parallel with this view, it appeare from the model atoms that in certain region only would another atom be in stable equilibrium. The chemist assumed that the attractive forces were confined to certain regions only, while the speaker sug. gested that the atoms exerted attractions all round, but in certain directions only could another atom remain in stable equilibrium.

If two similar atoms were brought together so that one valency region of one lay close to one on the other these two regions would be uninhabitable for other atoms, but the remaining valencies in each would be sented by $\mathrm{H}_{3} \mathrm{C}-\mathrm{CH}_{3}$. If two valency regions on each coincided with two in the other, compounds of the class $\mathrm{H}_{3} \mathrm{C}-\mathrm{CH}_{\text {: }}$ alone would be possible; and, finally, if three valency regions on each lay close to three on the other, but one valency region on each would be available, giving rise to compounds such as $\mathrm{HC}-\mathrm{CH}$. In
such cases the carbon atoms were held together by the structural forces already referre to.

RAILWAY RATE REGULATION. ITS BEARING UPON PU LIC TRANSPORTATION. By Janes L. Cowles.

"Uur present system of making railway rates is taxation without representation in its most dangerous form."-(Charles A. Prouty, Interstate Commerce Commissioner.)

So vital has become this question of "Taxation With out Representation," that a special session of Congres various railway-rate bills hitherto presented, however leave the present system of rates still in force, and continue its application in the hands of the same irrespon sible forces.

In view of past experiences, it seems to be very clea that only by the primary determination
Congress can the present evils be remedied.

Congress can the present evils be remedied. port of post-roads, railroads, trolley lines, public highways. If a free, representative government is to continue in this country, these taxes should be levied, primarily, by the representatives of the public in their various public assemblies. The common welfare on the cost-of-the-service principle, regardless of dis tance, and that the tax be low, uniform, stable, the same for all persons and all places.

From the foundation of the national government Congress has always regulated the transport tax on the cals. In 1863, while still engage in the struggle for the overthrow of slavery, Congress adopted the principle of uniform postal rates, regardless of distance, and
thus guaranteed forever equality of postal rights and thus guarantee forever equality of postal rights and
privileges throughout the republic. This act also ex privileges throughout the republic. This act also exarticles of merchandise in eight-ounce parcels.

articles of merchandise in eight-ounce parcels.
In 1870 Senator Sumner, of Massachusetts, congratulated the Senate that, slavery being dead, one more step might well be taken in behalf of a wider liberty by the establishment of a uniform one-cent letter rate.

In 1872 the postal service was extended to cover gen eral merchandise. In 1874 the eight-ounce merchandise of one cent for each two ounces, which is one-half the tax now levied on merchandise.

In 1885 Congress provided that publishers' merchan from postoffice to postoffice throughout the country at the rate of one cent a pound; this in parcels unlimite by law either in size or weight and only limite in practice by the size of the conventional mail sack parcels, from a pound to 200 pounds. And where free de-
livery exists (save, curiously enough, in the cities of publication) this merchandise is distribute to the cuspublication) this merchandise is distribute to the cus
tomers of publishers and newsdealers, by the piece, without extra charge.

The publishers' post offers a striking object lesson as to a practical method of protecting the private citien and the general business interests of the country against the unreasonable and uncertain transport rates
exacted by the managers of our public transport corporations-a striking object lesson as to the right soporations-a striking object lesson
lution of the railway-rate problem.

In this case the public corporation, the Congress of the United States, stands between the transport cor poration and the citizen, determining at once the pay. ments to be made by the government to the transport
corporation for its service and the tax to be paid by the citizen to the government for its service. The cor poration certainly secures its full dues. The smalles publisher and newsdealer pays the same tax, and re ceives the same service as the largest publisher and the largest newsdealer. Any newsboy can arrange with the government for the transport of his merchandise on as good terms as the largest news company. The publishers of Augusta, Me., are as well off as to the transport tax levied on their produce as are the publishers of New York, Chicago, or San Francisco.

Once Congress has extended to the whole public the protection now enjoyed by publishers and newsdealers, discriminations in transport rates will disappear. Al classes of persons and of business and all places within plies and send off their produce on equal terms as to ransport taxation.

This does not necessarily require the governmen ownership or even the government management of transport agencies. The running of railroad trains, the construction and reconstruction of railroads and allied services, the employment and discharge of transport employes, may still be left in the present control. The sole loss to the railroad manager will be his power of irresponsible taxation, his power to give rebates, to enrich or ruin persons and places at his will. Hence-
forth he will deal with the pubiic, not individually but en masse, in the person of the great public corporation, the United States government.

Congress already authorizes the Postal Department to hire mail cars. If contracts can be made for the con of a part of the public transport equipment, similar part of it. Every vehicle engaged in the mail service is necessarily engaged in interstate commerce,

The terms of these transport contracts may be very simple, so much per mile for the flying space, so much per mile per vehicle whether full or empty.

The reason for this common rate is clearly stated in Pay" by Vice-President Clough, of the Great Norther Railroad: "What costs the railroad company is space nearly the same, regardless of how it is occupied." nearly the same, regardless of how it is occupied."
The extension of the postal principle to general transport rates by the national government would be little more than the establishment, as a general law, of what has long been a common custom in interstate railway practice. It would insure stability of rates, freedom from discrimination, the possible reduction of transport taxation as improvements in transport
reduce the cost of the service rendered.

In an extended postal service we find at once the solution of the railway-rate problem and that irresistiof the republic.

\section{THE STANDARDIZATION OF CHEMICAL} ANALYSIS.

TII nee of some system whereby chemical analysis may be standardized has been made the subject of exhaustive treatment by Dr. W. F. Hillebrand and Mr. to differ in the analyses nothing new for chemists they will never cease to differ by reason of human fallibility and the limitations of all analytical methods without exception, but unless two chemists are able to assay or analyze the same sample with results accepta-
ble as a basis for buying and selling the analysts suffer in the estimation of those intereste in the transaction. If similar want of accord is of frequent occurrence, the burden of blame may be shifted and the art of analysis, even the science of chemistry itself, fall into disrepute among the unthinking. In any case the matter is one of grave concern in many ways, and

consideration of chemists as a body.

We may analyze the causes for the variations shown in the analyses of the same, or supposedy the same, samples, and, neglecting the inevitable personal factor, find that in certain cases the sampling was incorrect, their effect on the water was bad, the reagents iaulty, suspected, or that of several methods for reaching the same end one or more are of doubtful value unless used with that knowledge which can only come of long practice, sharpened by discriminating judgment. But in the ultimate analysis these distinct causes nearly all
lead back to one stem root, some defect in the early education of the chemist, for which the institutions that are yearly sending forth young chemists supposedly fitted to do good work in their chosen lines, are re sponsible.

It will, of course, be asked: In what respect have definite and comprehensive answer to this demand it is out of my power to give. The teaching of incorrect methods is neither wholly nor in large part to blame. The faults, if faults there be, are rather those of omission than of commission.

Many inquiries addressed by Dr. Hillebrand to the formation that few knew anything elicited the in quality of the water they were using though tion showed it to be bad in a few instances, and on the border line in others. Still less was known as to the quality of the reagents, except that they came from reputable firms. One admitte that a flaky sediment clear liquid above. If the sediment represented silica from the bottle, as may well have been, what had be unless they were in solution?

Is a student ever require to find out by actual test how good his water is, and both the kind and amount to ins contamination, if such there be? Is it customary the chatruct him in the testing of his reagents and as to all of the me contaminations to he lollowe to forth with the impression that the label C. P., while not a flawless title, is a sufficient guarantee for all the demands of technical analysis? Is he, in fact, ever cautioned to find out, by actual test, the errors with
which his work may be affected, due to imperfections in his tools of the kind just mentioned? And that without sirch knowledge and the ability to make correction for the defects, or the courage to fight for better materials with which to do, he will occupy a false position munity at large?

Only by such exercises can the young worker gain any knowledge as to his own power to good work, so essential.

There is in many of our institutions woful lack of supervision of the work of each individual student. which the student cannot learn for himself, and which he should be taught by a conscientious assistant, having little to do but devote his whole time to a limited number of workers. This brings me to the remark that no laboratory instructor should be required or allowed
to do outside work, either for his superiors or himself so as to encroach in any way upon the time that should be given to those under his supervision. This would necessitate a very decide increase in the corps of in structors, so as not to deprive them of opportunity for
research work. Once the fundamentals have been mas. tered, the worker, correctly started, may well be left more to his own resources, but even then he should against relapse from right ways, for giving needed ad. ditional information, and answering the proper queries that are pretty sure to occur to a good student. It is paratively few things thoroughly, mastering the whys and wherefores of every step, than a great many superficially and without acquisition of the underlying principles. It is only the one thus thoroughly grounded great danger.

OCCUPATIONS OF THE PHILIPPINE ISLANDERS. A MAJORITY of the Filipinos farm small tracts of land, and those living near the coast alternate this between duties of housekeeping and the weaving of hats, mats, and cloths, and are, therefore, included among those engaged in gainful occupations. This fact accounts for the excessive proportion of wagecivilize population. The number of female wageearners in the Philippines is proportionately double that of the United States and three times that of Porto Rico and Cuba. Of the female wage-earners, and the proportion engaged in agriculture and domestic service is much less than the corresponding proportions for the Unite States. Of the male wageearners, more than half are employed in agricultural pursuits, and so few are returned as manufacturers that the proportion of women employe in those pursuits is so large as to show that it is practically a line of feminine employment.

Farmers and farm laborers constitute more than two-fifths of all who are engaged in gainful occupa ufacturing much smaller proportion are engage in manin professional service is exceedingly small, forming less than 1 per cent of the entire number gainfully employed.

Among the Filipinos themselves there are 1,326 phyof the Chinese wage earners are merchants or sal of the foreign or white population a small proportion are engage in agriculture, but most are found in the trades and professions.

trades and professions.
Sixty per cent of the population of the city of Manila Sixty per cent of the population of the city of Manila
are employe in gainful occupations. This rather remarkable proportion appears to be due to the fact that the foreign element is very large and the proportion of young children, small. The figure, however, is much greater than for any considerable section of the
United States, the closest approach being in the State of Wyoming, where the proportion of persons gainfully occupied was 47.8 per cent.

While it is probable that the part playe by bacteria is not so important in the ripening of cheese as for merly supposed, the necessity for the lactic bacteria in acidifying the milk for the production of a good curd is well recognized. We also know that in some kinds teristic flavor so much relished by some. In addition, the supplying of certain bacteria. known as "langvey" in Holland, plays a most important part in preventing the deterioration of the cheese, owing probably to these organisms keeping down the growth of objectionable This latest discovery is likely to open foo products. in the dairy industry, as, in a sense, it does a way with 